\title{
Evaluation of antimotility effect of Lantana camara $L$. var. acuelata constituents on neostigmine induced gastrointestinal transit in mice
}

\author{
Lenika Sagar, Rajesh Sehgal and Sudarshan Ojha*
}

Address: Department of Biochemistry, Panjab University, Chandigarh - 160014 India

Email: Lenika Sagar - lenika@rediffmail.com; Rajesh Sehgal - rajeshsehgal1@rediffmail.com; Sudarshan Ojha* - s_ojha@pu.ac.in

* Corresponding author

Published: 17 September 2005

BMC Complementary and Alternative Medicine 2005, 5:18 doi:10.1186/1472-6882-5-18

This article is available from: http://www.biomedcentral.com/1472-6882/5//8

(C) 2005 Sagar et al; licensee BioMed Central Ltd.

This is an Open Access article distributed under the terms of the Creative Commons Attribution License (http://creativecommons.org/licenses/by/2.0), which permits unrestricted use, distribution, and reproduction in any medium, provided the original work is properly cited.
Received: 30 March 2005

Accepted: 17 September 2005

\begin{abstract}
Background: Lantana camara L. (Verbenaceae), a widely growing shrub which is toxic to some animal species, has been used in the traditional medicine for treating many ailments. The purpose of the present study was to evaluate the antimotility effects of Lantana camara leaf constituents in mice intestine.
\end{abstract}

Methods: Evaluation of antimotility activity was done in intestine of mice treated with Lantana camara leaf powder, Lantana camara methanolic extract (LCME), lantadene A, neostigmine and neostigmine + LCME. Neostigmine was used as a promotility agent. Intestinal motility was assessed by charcoal meal test and gastrointestinal transit rate was expressed as the percentage of the distance traversed by the charcoal divided by the total length of the small intestine. The antidiarrheal effect of LCME was studied against castor oil induced diarrhea model in mice.

Results: The intestinal transit with LCME at a dose of $500 \mathrm{mg} / \mathrm{kg}$ was $26.46 \%$ whereas the higher dose $(\mathrm{I} \mathrm{g} / \mathrm{kg})$ completely inhibited the transit of charcoal in normal mice. The \% intestinal transit in the neostigmine pretreated groups was 24 and II at the same doses respectively. When the plant extracts at 125 and $250 \mathrm{mg} / \mathrm{kg}$ doses were administered intraperitonealy, there was significant reduction in fecal output compared with castor oil treated mice. At higher doses (500 and 1000 $\mathrm{mg} / \mathrm{kg}$ ), the fecal output was almost completely stopped.

Conclusion: The remarkable antimotility effect of Lantana camara methanolic extract against neostigmine as promotility agent points towards an anticholinergic effect due to Lantana camara constituents and attests to its possible utility in secretory and functional diarrheas and other gastrointestinal disorders. This effect was further confirmed by significant inhibition of castor oil induced diarrhea in mice by various doses of LCME.

\section{Background}

Diarrhea is one of the most prevalent human disorders and understandably its remedy occupies a special place in the annals of medicine [1]. Neurohormonal mechanisms, pathogens, malnutrition, chronic diseases and drugs can alter gastrointestinal physiology resulting in changes in either secretion or absorption of fluid by the intestinal epithelium. Altered motility contributes in a general way to this process, as the extent of absorption, by and large, parallels transit time. Prokinetic agents, organophosphate 
Table I: Effect of Lantana camara leaf powder, LCME, lantadene A and neostigmine on small intestinal transit in mice.

\begin{tabular}{|c|c|c|c|}
\hline Treatment & $\begin{array}{l}\text { Total length of intestine } \\
(\mathrm{cm})\end{array}$ & $\begin{array}{l}\text { Distance traveled by charcoal } \\
\text { (cm) }\end{array}$ & $\%$ Intestinal Transit \\
\hline CMC Control & $45.66 \pm 6.24$ & $21.66 \pm 0.57$ & $47.25 \pm 6.10$ \\
\hline Leaf Powder ( $1 \%$ for 10 days) & $46.50 \pm 6.19$ & $15.50 \pm 7.70$ & $34.78 \pm 3.52^{* *}$ \\
\hline LCME (I g/kg) & $50.00 \pm 0.90$ & $0.50 \pm 0.01$ & $1.00 \pm 0.01 * * * *$ \\
\hline LCME $(500$ mg/kg) & $53.66 \pm 6.02$ & $11.00 \pm 6.02$ & $26.46 \pm 6.82^{* * *}$ \\
\hline LCME (250 mg/kg) & $48.30 \pm 1.36$ & $|5.30 \pm 0.5|$ & $31.74 \pm 1.49 * * *$ \\
\hline LCME (I 25 mg/kg) & $49.00 \pm 0.89$ & $19.00 \pm 3.58$ & $38.67 \pm 6.60 * * *$ \\
\hline Lantadene A (85 mg/kg) & $44.00 \pm 7.92$ & $18.01 \pm 7.37$ & $39.47 \pm 10.05^{* *}$ \\
\hline Lantadene A ( 170 mg/kg) & $47.00 \pm 4.73$ & $13.00 \pm 3.03$ & $27.34 \pm 4.58 * *$ \\
\hline Neostigmine $(I \mu g / k g)$ & $49.00 \pm 4.69$ & $34.33 \pm 9.15$ & $69.30 \pm 12.47^{* * * *}$ \\
\hline Neostigmine $(\mathrm{I} \mu \mathrm{g} / \mathrm{kg})+\mathrm{LCME}(\mathrm{I} \mathrm{g} / \mathrm{kg})$ & $48.00 \pm 3.00$ & $5.33 \pm 0.76$ & $11.10 \pm 1.14^{* * * *}$ \\
\hline Neostigmine $(\mathrm{I} \mu \mathrm{g} / \mathrm{kg})+\mathrm{LCME}(500 \mathrm{mg} / \mathrm{kg})$ & $50.50 \pm 0.70$ & $12.00 \pm 1.40$ & $24.00 \pm 2.19 * * *$ \\
\hline
\end{tabular}

Statistical analysis: Values are mean \pm S.D. of 6 observations in each group. Values having $\mathrm{P}<0.01$ were considered significant. **P $<0.01$, ***P $<0.00 \mathrm{I}$ as compared to control.

pesticides, nerve gases, surgery, irritation bowel syndrome, collagen vascular disease and diabetes are some of the pathophysiological conditions that may alter intestinal motility and transit time. Antimotility compounds such as diphenoxylate, loperamide, opium alkaloids, anticholinergics etc. have been tried against diarrheal disorders but often with side effects after prolonged use [2].

Acetylcholine, the vagal neurotransmitter, enhances and atropine, a known anticholinergic agent decreases intestinal motility and secretion. Although various derivatives and congeners of atropine (such as propantheline, isopropamide and glycopyrrolate) have been advocated in patients in peptic ulcer or with non-specific diarrhea, the prolonged use of such agents is limited by other manifestations of parasympathetic inhibition such as dry mouth and urinary retention [3]. There is, thus, a need for identifying new compounds and evaluating their antimotility activity and developing these as selective inhibitors that decrease gastric secretion and intestinal motility at doses that have minimal anti-cholinergic effects at other sites and are completely free from other adverse effects [4].

Lantana camara L. (Verbenaceae) is one of the most prevalent and noxious weeds causing hepatotoxicity in grazing animals $[5,6]$. Lantana poisoning causes obstructive jaundice and within a few hours of browsing upon its foliage, animals go off-feed and become severely constipated within $48 \mathrm{~h}$ [7]. On the contrary, Lantana plant has been reported to possess a number of medicinal properties $[8,9]$. Some metabolites isolated from their leaves possess antitumor activity [10], antithrombin activity [11], antiinflammatory, antinociceptive and antipyretic activity [12].
Present investigations were planned to study the effect of Lantana camara leaf powder, Lantana camara methanolic extract (LCME) and lantadene A administration on mice intestinal motility using neostigmine as a promotility agent. Antidiarrheal effect of LCME was studied using castor oil induced diarrhea in mice.

\section{Results}

The percent intestinal transit was increased significantly with neostigmine, but was decreased significantly by all concentrations of LCME and lantadene A. The intraperitoneal administration of the $\operatorname{LCME}(125,250 \& 500 \mathrm{mg} / \mathrm{kg})$ alone decreased the percent intestinal transit significantly. However, with a LCME dose of $1000 \mathrm{mg} / \mathrm{kg}$, intestinal transit was nearly abolished. Leaf powder (1\% of feed) feeding for 10 days reduced the \% intestinal transit by 34.78. Inhibition in \% intestinal transit by 85 and 170 $\mathrm{mg} / \mathrm{kg}$ lantadene A was 39.47 and 27.34 respectively. The prokinetic effect of neostigmine was opposed by both the doses $(1.0 \mathrm{~g} / \mathrm{kg}$ and $500 \mathrm{mg} / \mathrm{kg})$ of LCME and \% intestinal transit was reduced to 11 and 24 respectively (Table 1 ).

Diarrhea was apparent in all the animals of control group 45 minutes after the administration of castor oil and fecal count was taken for $4 \mathrm{~h}$. A marked reduction in the number of defecations over $4 \mathrm{~h}$ was observed with the i.p. administration of all doses of LCME. The animals of group 4 and 5 appeared to be completely constipated, where as those of group 2 and 3 showed a significant reduction in defecations as compared to control group (Table 2).

\section{Discussion}

The pathophysiological mechanisms underlying the loss of intestinal fluid in diarrhea have been the subject of much debate for decades [17]. Diarrhea may be caused by 
Table 2: Effect of Lantana camara methanolic extract (LCME) on castor oil-induced diarrhea in mice.

\begin{tabular}{cc}
\hline Treatments & Mean defecation in $\mathbf{4 ~ h}$ \\
\hline Castor oil + saline $(2 \mathrm{ml} / \mathrm{kg})$ & $24 \pm 3.10$ \\
Castor oil + LCME $(125 \mathrm{mg} / \mathrm{Kg})$ & $9 \pm 1.18^{* * *}$ \\
Castor oil + LCME $(250 \mathrm{mg} / \mathrm{kg})$ & $9 \pm 2.06 * * *$ \\
Castor oil + LCME $(500 \mathrm{mg} / \mathrm{kg})$ & $\mathrm{I} \pm 0.05^{* * *}$ \\
Castor oil + LCME $(1000 \mathrm{mg} / \mathrm{kg})$ & Completely constipated
\end{tabular}

Statistical analysis: Values are mean \pm S.D. of 4 observations in each group. Values having $\mathrm{P}<0.01$ were considered significant. $* * \mathrm{P}<$ 0.01 , $* * * P<0.001$ as compared to control.

an increase in osmotic load within the intestine, excessive secretion of electrolytes and water into the intestinal lumen, exudation of protein and fluid from the mucosa, infection and inflammation; and altered intestinal motility, resulting in rapid transit [18]. In most instances, multiple processes are simultaneously affected involving several factors, a particular factor becoming a dominant player in a given environment, however, motility and/or secretory disturbances usually remain a common denominator in most cases [2]. The mucosal lining of the gastrointestinal tract is provided with an extensive nerve supply from the enteric nervous system [19]. Neurotransmitters such as acetylcholine and noradrenaline and neurotransmitter candidates such as ATP, CGRP, CCK-8, ENK, GAL, GABA, serotonin, NO, somatostatin, SP, VIP etc have been implicated to different extents in normal and pathophysiological situations. Based on the knowledge gained about the divergent factors controlling the processes of secretion of electrolytes and motility, many interventional strategies have been adopted by researchers and numerous antidiarrheal compounds have been developed but not many compounds are without side effects and therefore there has always been a need for finding new ones.

Acetylcholine is the endogenous neurotransmitter at cholinergic synapses in the central and peripheral nervous system. The stimulation of vagal input to the gastrointestinal tract increases tone, amplitude of contraction and secretory activity of the stomach and intestine. Since such responses are inconsistently seen with administered acetylcholine, possibly because of poor perfusion and rapid hydrolysis by plasma butryl cholinesterase, use of neostigmine was made in the present investigation. Neostigmine is an inhibitor of acetylcholinesterase and increases the amount of acetylcholine at the synapse [3] and thus exerts a pro-kinetic effect. The results show that the Lantana camara leaf powder and LCME significantly reduced the \% intestinal transit in a dose dependent manner. Lantadene A also produced a statistically significant reduction in \% intestinal transit.
The induction of diarrhea with castor oil results from the action of ricinoleic acid formed from hydrolysis of its triglyceride in the oil $[20,21]$. The released ricinoleic acid produces changes in the transport of water and electrolytes resulting in a hypersecretory response and speeds intestinal transit [3]. The involvement of nitric oxide from neurons in the diarrhea induced by the castor oil has also been proposed [22]. Castor oil increases the induction of prostaglandins [23], causes changes in the permeability and mucosal injuries and stimulates PAF [24] biosynthesis which may result in inflammation of intestinal mucosa. The preventive administration of LCME was associated with significant protection against diarrhea induced by castor oil in mice. Lantana camara might possess some compounds with antisecretory properties which may account for its efficacy against diarrhea induced by castor oil in mice.

Lantana camara has been reported to be toxic to grazing animals such as cow, buffaloes, sheep and goats [7,25] and laboratory animals such as guinea pigs [8] and female rats [26]. In spite of its widespread toxicity in the Lantana affected animals, various parts of this plant have been used in the traditional medicines for treating cuts, ulcers, swelling, eczema, inflammation, fever etc [8]. Gastrointestinal stasis, ruminal stasis, constipation, discolorization of conjunctiva, photosensitization, decreased bile flow and urinary retention in the Lantana poisoned animals has been noticed [27-29]. These symptoms resembled those due to atropine toxicity i.e., anticholinergic excess [30,31].

Anti-dysenteric and anti-diarrheal properties of medicinal plants have been suggested to be due to tannins, alkaloids, saponins, flavonoids, sterols and triterpenes and reducing sugars [32]. The sesquiterpene lactones have been reported to have the ability to relax smooth muscles and thereby relieve gastrointestinal disorders [33]. The phytochemical analysis of the Lantana camara leaf extract has earlier been shown to contain flavonoids [34], terpenes [35] and their derivatives and pentacyclic triterpenoids [36]. These constituents may mediate the anti-diarrheal action of the Lantana camara extract. A verbascoside [37] isolated from Lantana camara has been shown to be an inhibitor of protein kinase $\mathrm{C}$. The role of this enzyme has been demonstrated in signal transduction, inflammation and smooth muscle contraction [38] and an inhibition of its activity by a constituent of Lantana camara shall result in decrease in motility. Although the anti-diarrheal properties of the reported active terpenoids are well established, aspects of their mechanism of action remain poorly understood. Terpenes, flavonoids and terpenoid derivatives may act by inhibiting release of autocoids and prostaglandins $[39,4]$ thereby inhibit the motility and secretion induced by neostigmine. Intestinal motility alterations in Lantana camara foliage poisoned sheep has 
been described by Pass et al. [40] but no mechanism has been suggested.

\section{Conclusion}

The remarkable antimotility effect of Lantana camara methanolic extract against neostigmine as promotility agent points towards an anticholinergic effects due to Lantana camara constituents and attest to its wide range of utility in secretory and functional diarrheas and other gastrointestinal disorders in the folklore. This effect was further confirmed by significant inhibition of castor oil induced diarrhea in mice by various doses of LCME. Whatever may be the mechanism of action, LCME may be useful in a wide range of diarrheal states due to disorders of intestinal transit and secretion. Further studies with purified constituents are needed to completely understand the mechanism of anti-diarrheal action of Lantana camara.

\section{Methods}

Plant material and preparation of extract (LCME)

Fresh leaves of Lantana camara (red variety) were collected from Palampur (Himachal Pradesh, India). The air-dried, pulverized leaves $(100 \mathrm{~g})$ were then exhaustively extracted with methanol $(800 \mathrm{ml})$. The extract was treated with 20 $\mathrm{g}$ of activated charcoal and evaporated under reduced pressure. The semi-solid residue $(10 \%$ yield, w/w) obtained was blackish brown in color, henceforth called Lantana camara methanolic extract (LCME). Different doses of LCME (125-1000 mg/kg) and lantadene A (85 and $170 \mathrm{mg} / \mathrm{kg}$, i.p.) were prepared in $0.25 \%$ carboxy methyl cellulose (CMC) just before use. The injection volume for each treatment varied from $0.2-0.3 \mathrm{ml}$ depending upon the weight of the animal. The control group animals were given equivalent volumes of $0.25 \% \mathrm{CMC}$.

\section{Preparation of lantadene $\boldsymbol{A}$}

Lantadene A was prepared by method of Barton et al. [13] and its purity $(94 \%)$ was determined by the method of Sharma et al. [14].

\section{Animals and treatments}

Male mice (laca strain) weighing 20-25 g were obtained from central animal house of Panjab University, Chandigarh and were housed in polypropylene cages under hygienic conditions for one week for acclimatization. The animal ethics committee of Panjab University had approved the study protocol of this project. The animals were given the following treatments:

\section{Control}

This group received standard pellet diet (Ashirwad Industries, Chandigarh, India) and was given $0.25 \%$ CMC, 30 minutes before charcoal meal test.
Lantana camara leaf powder treated

The animals from this group received leaf powder orally ( $1 \%$ of feed) for 10 days prior to the assessment of intestinal motility.

\section{LCME treated}

The animals from this group received a single dose of LCME $(125,250,500$ and $1000 \mathrm{mg} / \mathrm{kg}$, i.p.), $30 \mathrm{~min}$ before charcoal administration.

Lantadene A treated

A single dose of lantadene A ( 85 and $170 \mathrm{mg} / \mathrm{kg}$, i.p.) was injected.

\section{Neostigmine treated}

Neostigmine obtained from Tablets (India) Limited, Chennai, India was administered subcutaneously ( $1 \mu \mathrm{g} /$ $\mathrm{kg}$ ) in normal saline.

\section{Neostigmine + LCME treated}

This group consisted of two subgroups:

Neostigmine ( $1 \mu \mathrm{g} / \mathrm{kg}$, s.c.) and LCME ( $1 \mathrm{~g} / \mathrm{kg}$, i.p.) was administered to one subgroup.

The second subgroup received neostigmine ( $1 \mu \mathrm{g} / \mathrm{kg}$, s.c.) and LCME (500 mg/kg, i.p.)

The animals were fasted for 24 hours prior to the experiment but permitted water ad libitum. On the day of the experiment, treated groups received LCME, lantadene A, neostigmine, neostigmine + LCME.

After 30 minutes of having given the doses as described above, intestinal motility was assessed by orally administrating semisolid test charcoal meal $(0.3 \mathrm{ml}$ per mouse) consisting of $10 \%$ charcoal and $5 \%$ gum acacia. The animals were sacrificed 30 minutes later. The abdomen was opened and the entire small intestine starting from the pyloric end was removed and placed on the blotting paper. The distance traveled by charcoal was measured and expressed as percent intestinal transit [15].

$\%$ Intestinal transit $=\frac{\text { Distance traveled by charcoal }}{\text { Total length of small intestine }} \times 100$

\section{Castor oil induced diarrhea}

Mice were divided into five groups of four animals each, diarrhea was induced by administering $1 \mathrm{ml}$ of castor oil (Qualikems Fine Chemicals Pvt. Ltd. New Delhi, India) orally to mice. Group 1 served as control $(2 \mathrm{ml} / \mathrm{kg}$, i.p. saline), groups 2, 3, 4 and 5 received $\operatorname{LCME~}(125,250$, 500 and $1000 \mathrm{mg} / \mathrm{kg}$, i.p.) $1 \mathrm{~h}$ before castor oil administration. The number of both wet and dry diarrheal drop- 
pings was counted every hour for a period of $4 \mathrm{~h}$ and was compared with that of the positive control animals [16].

\section{Statistical analysis}

The results are represented as mean \pm S.D. Dunnett's test was used for the evaluation of data and $\mathrm{P}<0.01$ accepted as significant.

\section{Abbreviations}

LCME: Lantana camara methanolic extract GIT: Gastrointestinal tract, VIP: vasoactive intestinal peptide, GABA: gamma aminobutyric acid, CCK8: cholecystokinin octapeptide, CGRP: calcitonin gene-related peptide, GAL: galanin, SP: substance P, ENK: Enkephalin.

\section{Competing interests}

The author(s) declare that they have no competing interests.

\section{Authors' contributions}

LS and RS were responsible for practically carrying out the experiments

$\mathrm{SO}$ - supervised the design and co-ordination of the study

\section{Acknowledgements}

The authors are grateful to University Grants Commision, New Delhi, India for providing funds for research and fellowship to LS

\section{References}

I. Massee B, McGahey C: A Framework for Action; Child Diarrhea Prevention. Global healthlink, a publication of the Global Health Council, www.globalhealth.org 2001.

2. Harrison TR: Diarrhea and Constipation. In Principles of internal medicine 16th edition. New York: Macgraw Hill; 2005:224-232.

3. Hardman JG, Limbird LE: Goodman's and Gilman's: Drugs affecting gastrointestinal function. In The pharmacological basis of therapeutics I0th edition. New York: Macgraw Hill; 2001: 1023-1024.

4. Chitme HR, Chandra R, Kaushik S: Studies on anti-diarrhoeal activity of Calotropis gigantea $\mathbf{R}$. Br. in experimental animals. J Pharm Pharmaceut Sci 2004, 7:70-75.

5. Sharma OP, Makkar HPS, Dawra RK: A review of the noxious plant Lantana camara. Toxicon 1988, 26:975-987.

6. Sharma OP, Makkar HPS: Lantana - the foremost livestock killer in Kangra district of Himachal Pradesh. Livestock Adv 1981, 6:29-31.

7. Sharma OP, Dawra RK, Makkar HPS: Toxicity of isolated lantana (Lantana camara L.) constituents to male and female guinea pigs. Vet Hum Toxicol 1989, 3 I: 10-13.

8. Ghisalberti EL: Lantana camara Linn. (Review). Fitoterapia 2000, 7l:467-485

9. Duke, James A: Handbook of phytochemical constituents of GRAS herbs and other economic plants. Boca Raton, FL. CRC Press; 1992.

10. Shashi BM, Niranjan PS, Subodh KR, Sharma OP: Potential Antitumor Agents fromf Lantana camara: Structures of Flavonoid and Phenylpropanoid Glycosides. Tetrahedron 1994, 50:9439-9446.

II. O' Neill MJ, Lewis JA, Noble HM, Holland S, Mansat C, Farthing JE, Foster G, Noble D, Lane SJ, Sidebottom PJ, Lynn SM, Hayes MV, Dix $\mathrm{CJ}$ : Isolation of translactone-containing triterpenes with thrombin inhibitory activities from the leaves of lantana camara. J Nat Prod 1998, 6 I:1328-1331.

12. Uzcategui B, Avila D, Heberto SR, Quintero L, Ortega J, Gonzalez YB: Anti-inflammatory, antinociceptive and antipyretic effects of
Lantana trifolia Linnaeus in experimental animals. Investigacion Clinica 2004, 45:4.

13. Barton DHR, De Mayo P, Orr JC: Triterpenoids Part XXIII: The nature of lantadene A. J Chem Soc 1956:4160-4I62.

14. Sharma S, Singh A, Sharma OP: An improved procedure for isolation and purification of lantadene $A$, the bioactive pentacyclic triterpenoid from Lantana camara leaves. Journal of Medicinal and Aromatic Plant Sciences 1999, 21 :686-688.

15. Jabbar S, Khan MTH, Choudhuri MSK, Gafur MA, Ahmad K: Effect of Semicarpus anacardium Linn. on acute experimental diarrhea. Ham Med 1999, XLII:48-53.

16. Awouters F, Niemegeers CJE, Lenaerts FM, Janseen PAJ: Delay of castor oil diarrhea in rats; a new way to evaluate inhibitors of prostaglandin biosynthesis. Journal of Pharmacy Pharmacology 1978, 30:41-45.

17. Lundregen $\mathrm{O}$ : Enteric nerves and diarrhea. Pharmacology and Toxicology 2002, 90:109-120.

18. Korman LY: Secretory and miscellaneous noninfectious diarrhea. In A Pharmacologic Approach to gastrointestinal disorders Edited by: Lewis JH. Williams and Wilkins, Baltimore; 1994:28I-29I.

19. Furness JB, Costa M: The enteric nervous system. Churchill Livingstone, New York; 1987.

20. Iwao I, Terada Y: On the mechanism of diarrhea due to castor oil. Jpn J Pharmacol 1962, I2: I37-I45.

21. Watson WC, Gordan RS: Studies on the digestion absorption and metabolism of castor oil. Biochem pharmacol 1962 , I I :229-236

22. Uchida M, Kato $Y$, Matsuede K, Shode R, Muraoka A, Yemato S: Involvement of NO from nerves in diarrhea induced by castor oil in rats. Jpn J Pharmacol 2000, 82:168-170.

23. Saito T, Mizutani F, Iwanaga $Y$, Morikawa $K$, Kato $H$ : Laxative and anti-diarrheal activity of polycarbophil in mice and rats. Jpn J Pharmacol 2002, 89: I33-I4I.

24. Izzo AA, Gaginella TS, Mascolo N, Capasso S: Recent findings on the mode of action of laxatives: the role of platelet activating factor and nitric oxide. Trends Pharmacol Sci 1998, 19:403-405.

25. Kellerman TS, Coetzer JAW, Naude TW: Plant poisoning and mycotoxicosis of livestock in Southern Africa Oxford University Press, Cape Town; 1988.

26. Akhter $M H$, Mathur $M$, Bhide NK: Skin and liver toxicity in experimental Lantana camara poisoning in albino rats. Indian J Physiol Pharmacol 1990, 34:13-16.

27. Pass MA, Seawright AA, Heath TJ: Lantadene toxicity in sheep. A model for cholestasis. Pathology 1979, I I:89-94.

28. Dhillon KS, Paul BS: Clinical studies of Lantana camara L. poisoning in buffalo calves with special reference to its effect on rumen motility. Indian J Animal Sci 1971, 4 I:945-948.

29. Sweeney MC, Pass MA: The mechanism of ruminal stasis in lantana poisoned sheep. QJ Exp Physiol Cogn Med Sci 1983:30I-3I4.

30. Holson D, Oster N: Constipation. eMedicine 200I, 2:SI-9.

31. Bruns John J: Toxicity, Anticholinergic. eMedicine 200I, 2:SI-I0.

32. Longanga_Otshudi A, Vercruysse A, Foriers A: Contribution to the ethnobotanical, phytochemical and pharmacological studies of traditionally used medicinal plants in the treatment of dysentery and diarrhea in Lomela area, Democratic Republic of Congo (DRC). I Ethnopharmacol 2000, 7 I:4 I I-423.

33. Heinrich M, Robles M, West JE, Ortiz de Montellano BR, Rodriguez E: Ethnopharmacology of Mexican asteraceae (Compositae). Annu Rev Pharmacol Toxicol 1998, 38:539-565.

34. Pan WD, Mai LT, Li YJ, Xu XL, Yu DQ: Studies on the chemical constituents of the leaves of Lantana camara. Yao Xue Xue Bao 1993, 28:35-39.

35. Begum S, Wahab A, Siddiqui BS: Pentacyclic triterpenoids from the aerial parts of Lantana camara. Chem Pharm Bull 2003, 5 I: I34-137.

36. Ahmed ZF, Shoaib AM, Wassel GM, Sayyad SM: Phytochemical study of Lantana camara $L$. Planta Med 1972, 2 I:282-288.

37. Herbert JM, Maffrand JP, Taoubi K, Augereau JM, Fouraste I, Gleye J: Verbascoside isolated from Lantana camara, an inhibitor of protein kinase C. J Nat Prod 1991, 54:|595-600.

38. Sales ME, Sterin-Borda L, de Bracco MM, Borda ES: Tyrosine kinase regulatory action on ileal muscarinic effects of IFN-gamma. J Interferon Cytokine Res 1999, 19:375-382.

39. Nikiema JB, Vanhaelen Fastre R, Vanhaelen M, Fontaine J, De Graef C, Heenen M: Effects of anti-inflammatory triterpenes isolated 
from Leptadenia hastate latex on keratinocyte proliferation. Phytother Res 200I, 15:131-134.

40. Pass MA, Heath TJ: The effect of Lantana camara on intestinal motility in sheep. J Comp Path 1978, 88:149-156.

\section{Pre-publication history}

The pre-publication history for this paper can be accessed here:

http://www.biomedcentral.com/1472-6882/5/18/prepub

Publish with Biomed Central and every scientist can read your work free of charge

"BioMed Central will be the most significant development for disseminating the results of biomedical research in our lifetime. " Sir Paul Nurse, Cancer Research UK

Your research papers will be:

- available free of charge to the entire biomedical community

- peer reviewed and published immediately upon acceptance

- cited in PubMed and archived on PubMed Central

- yours - you keep the copyright

Submit your manuscript here:

http://www.biomedcentral.com/info/publishing_adv.asp 